\title{
The Nexus Between Population and Economic Growth In Ethiopia: An
}

\section{Empirical Inquiry}

\author{
Adisu Abebaw Degu ${ }^{\dagger}$

\begin{tabular}{l}
\hline ARTICLE INFO \\
\hline Article History \\
Received $24 \quad$ December \\
2019; \\
Accepted 4 February 2020 \\
\hline JEL Classifications \\
$\mathrm{O} 2$, O15, J1
\end{tabular}

Department of Economics, Salale University, Fiche, Oromia Regional State of Ethiopia ABSTRACT

Purpose:

The link between population growth and economic growth has been becoming of most significant interest for researchers. However, there is no consensus among economists and researchers about the interaction between population and economic growth. Using timeseries data spanning from the period 1981 to 2018, this study examined the populationeconomic growth nexus in the second most populous African nation-Ethiopia.

Design/methodology/approach:

The study used yearly time series data spanning from 1981 to 2018, Augmented DickeyFuller (ADF) and Phillips-Perron (PP) unit root tests, Autoregressive Distributed Lag (ARDL) co-integration approach and Toda-Yamamoto Causality tests.

Finding:

Population and economic growth (Proxied by GDP) have a long-run association, as confirmed by the bound test co-integration approach. From ARDL model estimates, population growth is found to have a negative and significant effect on economic growth, both in the short-run and in the long-run. Likewise, growth in GDP affects population growth positively and significantly-both in the short-run and long-run. The TodaYamamoto Granger-Causality test revealed that, there is a unidirectional causality running from population to economic growth.

\section{Research implications:}

The current (as of 2019) number of the total population of Ethiopia exceeds 110 millionmaking the country the second-most populous nation in Africa. With the prevalence of high fertility rate and mortality rate, unemployment, and poverty, the population is not expected to bring economic development in general and economic growth in particular. Hence, it is

Keywords:

Growth

Population

ARDL,

Toda-Yamamoto Causality, Ethiopia advised to the concerned body that anti-natal policies that discourage the fertility rate, need to be re-considered to supplement with economic growth policies.

Originality/value:

This paper provides an empirical study of population-economic growth nexus in Ethiopiaa low-income country with a rapidly growing economy but also a rapidly increasing population and labor force. An understanding of such an issue would provide a reliable input for formulating development policies. However, up to the best of my knowledge, there is limited empirical research about population-growth nexus growth for the case of Ethiopia.

\section{Introduction}

Population growth of a country increase whenever the total birth rate of the country exceeds the total death rate of the nation or, when the total emigration of the country is higher than the total immigration (Dullah et al., 2011). There is a multi-directional relationship between population and economic growth. However, it has been accepted that economic growth is mainly affected by the population-since more human activities drive the economy that, inturn, accelerates economic growth (Adediran, 2012).

Population dynamics and its effects on economic outcomes have been an age-long debate (Dauda \& Aziakpono, 2015). And it has been a subject of major debates in the economic and social science literature. In general, there are three strands about the consequence of population growth on the overall economic development of a nation.

Some scholars argue that rapid population growth (high fertility and emigration rate) hinders economic development-leading to lower economic growth and poverty (Gorge et al., 2016). Robert Malthus (1798), in his theory of population, contended that population growth inescapably led to poverty-fundamentally, for it would always surpass food supplies (Dennis \& Robert, 2008). Other researchers (they are also known as the Revisionist)

${ }^{\dagger}$ Corresponding Author: Adisu Abebaw Degu

Email: adisu278@gmail.com

DOI: 10.25103/ijbesar.123.05 
have argued that rapid population growth promotes economic growth-by increasing the stock of human capital, and even by prompting technological and institutional changes (Admassie et al., 2015).

According to (Furuoka, 2010), in most developing countries, the demographic dynamics found to be encouraging for economic development-rises living standards. This is because in developing countries, population growth enlarges market size and increases competition in marketing activities. Even some other researches have established that population growth has an indefinite effect on economic growth (Bloom et al., 2003; Admassie et al., 2015). However, there is no over-all agreement among researchers about the proper role of the population in the economic growth path (Furuoka, 2016). Population expansion affects many phenomena, such as; the age structure of a country's population, migration, economic inequality, and the amount of labor force; these factors, in turn, affect the overall economic growth (Wesley, 2017).

In developing countries, however, it has been accepted that rapid population growth and high fertility rate could have negative consequences in economic and social development (Dennis \& Robert, 2008). Population growth, although it is not the fundamental cause of low levels of living, serves to worsen the problems of underdevelopment and makes development possibilities unattainable in developing countries (Assefa, 1994).

In general, population dynamics have a significant impact on any country's economic performance depending on the economic position of countries. On the one hand, the declining birth rate in the developed countries leads to shortages of labor supply and put pressure on their pension systems. On the other hand, increasing fertility in developing nations has been viewed as a potential obstacle to their economic and social development (Furuoka, 2010). Today developing countries share the most significant portion of the world's population. According to Worldometers (2019), the total Population of the world is estimated to be 7.71 billion (as of 2019) of which, African, Asian, and Latin American countries (mostly poor countries) cover more than $85 \%(6,557,556,350$ people). From the Africa region, Nigeria and Ethiopia are the first and the second most populous nations, respectively.

In 1980 the total population of Ethiopia was $35,141,712$ people with a $1.53 \%$ annual growth rate. This figure has been changing to $47,887,865$ in $1990,66,224,804$ in $2000,76,346,311$ in $2005,87,639,964$ in 2010 and $100,835,458$ in 2015. According to the CIA (2019), the current population of Ethiopia is estimated approximately $113,171,288$ people, of which 52.82 million are labor force. However, this high population growth phenomenon has not been optimally connected to economic growth. Though Ethiopia having registered a 10.9\% annual growth in GDP (CIA, 2019), the unemployment rate exceeds $17.5 \%$, and $29.6 \%$ of the total Population live below the poverty line.

Hence, this rising population of Ethiopia needs to be studied; since it impacts the economic growth of the country. However, there is limited empirical research about population-growth nexus growth for the case of Ethiopia. Therefore, this paper provides an empirical study of the effect of population on the economic growth of Ethiopia-a low-income country with a rapidly growing economy but also a rapidly increasing population and labor force. An understanding of such an issue would provide a reliable input for formulating development policies. Accordingly, this paper investigates the interaction between population dynamics and economic growth in Ethiopia. More specifically, this study tries to answer the following question: Does population growth leads to economic growth in Ethiopia? What is the relationship between population and economic growth in Ethiopia? Is there any causality between population growth and population growth in Ethiopia?

The rest of this paper is organized as follows: a review of literature, methodology, results and discussion, Summary and Conclusion, and reference.

\section{Literature Review}

There is an on-going debate concerning the population-growth nexus (Furuoka, 2016). The argument started when Malthus (1798) published his book entitled “An Essay on the Principle of Population." According to Malthus, the causation between population increase and economic growth is bi-directional. Higher economic growth increased the population by exciting early—marriage and higher fertility rates, and by improve health standard-reducing mortality, while a rapid population growth depressed economic growth through diminishing returns (Dullah, 2011). For about two centuries, since the formation of the Malthus theory of population, researchers have been debating about the role of population growth in the path of economic development.

The arguments, in general, can be classified into two schools of thought-pessimistic and optimistic views (Furuoka, 2016). The first view, popularly referred to as population pessimism, follows the line of Malthusian and neo-Malthusian arguments of adverse influence of population variables on economic prosperity (Dauda \& Aziakpono, 2015). Malthus supposed that population to grow geometrically, while food production to grow arithmetically, and this population-economic growth interaction is the main crux of the Malthusian model (Temitope et al., 2013). Others (such as Linden, 2017) argued that higher population growth has been and will continue to be challenging for economic growth. Since more and more people use more of the limited scare resources, it will ultimately reduce the long-term potentials of growth. The second view - optimistic view, justifies that population growth leads to economic growth. A large population increases market size and competition; it also increases the labor supply.

In other literature, there appears to be some consensus that population and economic growth are inter-dependent. However, their nature of the interaction between seems to depend on the particular circumstances-such as on the population age structure in the different countries and regions of the world (Wesley, 2017).

When Malthus (1798) discussed the theory population, he assumed that population growth increases at a geometric rate and food production (the level of subsistence) at an arithmetic rate. He presupposed that population growth has a depressing effect on per capita output growth; this is because production growth cannot keep up at the same pace as population growth. The main factor for this contention is that land (hence agriculture) exhibits 
diminishing returns to scale - as more and more inputs employed. Thus, Malthus asserted that if "preventive check" (such as late marriage, never marry, education) failed to curb fertility, what he termed "Positive checks" (Famine, war, plague, starvation) will work then.

A neoclassical growth model such as Solow (1956), considers the population as exogenous (independent on economic dynamics) following arithmetic pattern expansion. Solow (1956) assumes a constant population growth and shows how economic growth is affected by population growth. Population growth, he thought, increases labor force supply and thus increases output per-worker growth rate in one hand, population growth reduces physical capital per worker; that eventually reduces productivity and output per-worker growth. In this case, changes in population growth rates affect the economic growth of the country, and it would be detrimental for economic development.

In recent years, different economists and researchers are involved by the population-growth nexus of developing countries. However, empirical studies have found a mixture of negative and positive effects as well as of no effects evidence. Jorge et al. (2016) analyzed the dynamic interaction between population growth and economic growth in Mexico. By using a structural break co-integration and time series data for the period 1960-2014, their study revealed the presence of a long-run relationship between population and economic growth in Mexico. Moreover, their study confirmed that, there is bi-directional causality between population and economic growth in Mexico. Temitope et al. (2013) examined the effect of population dynamics such as mortality and fertility, on the economic growth of 35 subSaharan African countries. Using the five-year average data from 1970 to 2005, pooled OLS and the dynamic panel data analysis, their study results showed that, total fertility rate and life expectancy at birth had a negative and a positive influence on economic growth, respectively.

Dauda and Aziakpono (2015), examined the effect of population dynamics on the economic growth of West African countries over the period 1970 to 2011 . By using fixed effects and random effects estimation methods, their findings revealed that increase in Population, labor force, and fertility improved economic growth. In contrast increase in infant mortality lowered the level of growth in the West African countries. Akinbode et al. (2017), using yearly data obtained from 1970 to 2014 , co-integration and causality test, examined the dynamic relationship between population and economic growth in the Nigerian economy. Accordingly, the study revealed that both variables had a long-run relationship; moreover, uni-directional causality between population and economic growth running from former to the later was found. Ademola (2019) investigated the nexus between demographic dividend and economic growth in the Nigerian economy. By using time series data spanning from the year 1970 to 2017 , and multivariate VAR model, their study showed that, the innovation in gross enrolment contributed to economic growth relative to innovation in economic support ratio. By using historical data over the past 200 years, Wesley (2017) studied the links between population growth, per capita output growth, and overall economic growth of the world. His result revealed that, low population growth in rich countries is likely to create social and economic problems whereas; high population growth in developing countries may slow their economic development. He also proposes that international migration could be used to adjust such imbalances.

Using time-series data spanning from 1980 to 2010 and descriptive statistics as well as regression analysis, Eli and Amade (2015) investigated the impact of population growth on the economic growth of the Nigerian economy. The study showed the existence of a positive relationship between economic growth and export growth, population, and fertility, while negative links were found between economic growth and, life expectancy and crude death rate. Emmanuel (2015), empirically examined the relationship between population growth and economic growth in Ghana. By using time series data spanning from the period 1980-2013, Bounds test approach co-integration and Granger causality test, the study reveals a negative relationship between population and economic growth in the short-run and, unidirectional causality in the long-run between them. Besides, it revealed that population density and labor force impact positively, whereas the unemployment rate negatively impacts economic growth in the long run. By using the Vector Autoregression Estimation technique for an annual time series data ranging from the period 1963 to 2009 , Thuku et al., (2013) investigated the relationship between population growth and economic growth in Kenya. Accordingly, their study revealed that the population has a positive influence on economic growth, and subsequently promotes the development of the country. Dao (2012), by using Least Square Estimation on linearly multivariate regression and using data on 43 countries, analysed population and economic growth in developing countries. The result revealed that GDP per-capita, linearly, and negatively depends on population growth, but fertility rate and urban growth were found to be statistically insignificant interaction with planned family planning and significant socio-economic structural changes.

However, there a scanty empirical study conducted on a similar issue for the case of Ethiopia. Terefe (2018) investigated the relationships between economic development and population indicators in Ethiopia. By using timeseries techniques and descriptive analysis, the study showed that the growth of GDP negatively interacts with population growth, total fertility rate, child mortality rate, infant mortality rate and unemployment. Besides, economic growth positively interacts with primary and secondary school enrolments, technical and vocational education and training, undergraduate studies, and health. Nonetheless, his analysis lacks econometric modelsmaking inference between population and development impossible. Generally, from the above studies, it is concluded that population-growth nexus lead to a mixed result.

\section{Methodology \\ 3.1 Data}

This study uses a time series secondary obtained from the World Bank (WB). The annual time series data used in this study are; gross domestic product based on 2010 constant price (as a proxy of economic growth), and population growth of Ethiopia. The data used in the study range from the period 1981 to 2018; the sample used is relatively DOI: 10.25103/ijbesar.123.05 
small. The econometric analysis of the data was executed in three-stage procedures: (1) Stationary/unit root tests, (2) Bounds test for co-integration and estimation of the long-run and Short-run coefficient from the ARDL method, and (3) the Toda-Yamamoto (TY) causality test.

\subsection{Autoregressive Distributed Lag (ARDL) approach to Co-integration}

Co-integration can be defined as the existence of long-term and equilibrium relationships between different series (Matchaya, et al., 2013). This makes the co-integration method an ideal technique to determine whether the long-term relationships between variables exist or not. However, before proceeding to the co-integration testing, the levels of integration of variables need to be tested by using Augmented Dickey-Fuller (ADF) and Phillips-Perron (PP) unit root test. Both Augmented Dickey-Fuller (ADF) (1981) and Phillips-Perron (PP) (1988) unit root tests are used mainly in the literature (Umit and Alkan, 2016).

This study relied on using the ARDL model. Autoregressive Distributed Lag models are suitable for small sample sizes, unlike other VAR methods like the Johansen co-integration technique, which in the same situation are vulnerable for substantial loss of degrees of freedom (Emmanuel, 2015). Autoregressive Distributed Lag models generate consistent estimates of long-run coefficients that are asymptotically normal, whenever the variables are fully integrated of order zero, I(O), purely integrated of order one I(1) or a mixture of $\mathrm{I}(0)$ and I(1) (Pesaran et al.,2001). It also provides unbiased and efficient estimates of the long-run model and valid t-statistics even if the variables under consideration are endogenous. This is possible because it avoids the problems of serial correlation and endogeneity (Afzal et al., 2010). Consider the following equations for which the ARDL model constructed when economic growth is the dependent variable.

$\Delta(\ln G D P)_{t}=\beta_{0}+\sum_{i=1}^{p} \alpha_{1 i} \Delta\left(\ln G D P_{t-1}\right)+\sum_{i=1}^{p} \alpha_{2 i} \Delta\left(\ln P O P_{t-1}\right)+\beta 1\left(\ln G D P_{t-1}\right)+\beta 2\left(\ln P O P_{t-1}\right)+\mu_{t} \ldots \ldots \ldots . . .(1)$

Where, lnGDP and lnPOP represents the natural logarithm of gross domestic product (based on 2010 constant price) and the natural logarithm of population, respectively. $\alpha \mathrm{i}$ and $\beta \mathrm{i}$ are the short-run and long-run coefficients of explanatory variables, respectively. The second ARDL model with the population as the dependent variable is expressed as follows.

$\Delta(\ln P O P)_{t}=\beta_{0}+\sum_{i=1}^{p} \alpha_{1 i} \Delta\left(\ln P O P_{t-1}\right)+\sum_{i=1}^{p} \alpha_{2 i} \Delta\left(\ln G D P_{t-1}\right)+\beta_{1}\left(\ln P O P_{t-1}\right)+\beta_{2}\left(\ln G D P_{t-1}\right)+\mu_{t} \ldots \ldots \ldots$.

In the equations above ( 1 and 2$)$, all the variables are previously defined, $\ln$ denotes logarithmic operator, $\Delta$ is the differenced of a variable, $\mu \mathrm{t}$ are error terms, and $\mathrm{i}$ is the maximum lag number.

The F-statistic is carried out on the joint null hypothesis that the coefficients of the lagged variables are equal to zero $(\beta 1=\beta 2=0)$ and alternative hypothesis $\beta 1 \neq \beta 2 \neq 0$, to test the long-run relationship of the model. Since the ARDL procedure is sensitive for a given lag length, the number of appropriate lags in the dependent variable chosen using Akaike Information Criteria (AIC) and Schwartz Information Criteria (SIC) to ensure that the errors are white noise.

Pesaran, et al. (2001) suggested a bounds test for co-integration with two sets of asymptotic critical values to test the null hypothesis of no co-integration. The first set of critical values estimated given all variables in a study are $\mathrm{I}(0)$, while the second set of critical values estimated given all variables are I(1). If the F-statistics exceeds the upper bounds of critical values, the null hypothesis of no co-integration cannot be accepted. Likewise, if the F-statistics is lower than the lower bounds of critical values, the null hypothesis of no co-integration is accepted. However, if the Fstatistics lied in between the upper and the lower bound of the critical values, an inconclusive inference can be made.

After the existence of co-integration is confirmed, a dynamic error correction model (ECM) can be derived from the ARDL model. If the error correction term is negative and statistically significant, it will establish the long-run linkage between population and economic growth in Ethiopia.

$$
\Delta(\ln G D P)_{t}=\beta_{0}+\sum_{i=1}^{p} \beta_{1 i} \Delta\left(\ln G D P_{t-1}\right)+\sum_{i=1}^{p} \beta_{2 i} \Delta\left(\ln P O P_{t-1}\right)+\Upsilon E C T_{t-1}+\mu_{t} \ldots \ldots \ldots
$$

Equation (3) and (4), respectively, represents the short-run dynamics for the lnGDP and lnPOP models.

$$
\Delta(\ln P O P)_{t}=\beta_{0}+\sum_{i=1}^{p} \beta_{1 i} \Delta\left(\ln P O P_{t-1}\right)+\sum_{i=1}^{p} \beta_{2 i} \Delta\left(\ln G D P_{t-1}\right)+\Upsilon E C T_{t-1}+\mu_{t}
$$

Where $\beta^{\prime}$ s are the coefficients associated with short-run dynamics of the model coverage to equilibrium, ECTt- 1 is the error correction term, and $\mu$ is a stochastic error term.

\subsection{Toda -Yamamoto approach for Causality analysis}

According to Ademola (2019), econometric literature proposes, contingent on time-series features of variables, three distinct methodological alternates to empirically analyze the dynamic interactions between time series variables. These are, a VAR Model with the level, I $(0)$ data, a VAR model with first-differenced, I(1) data, and a vector error correction model (Hundie, 2014). However, VAR estimation, as argued by Toda and Philips (1994), often comprehends nuisance parameters. 
According to Santos and Chris (2013), a two-variable Granger-Causality test, unless it considers the effect of other variables, is subject to specification bias. Even if researchers can still test the significance of individual coefficients with t-statistic, one may not be able to use F-statistic to test the Granger-Causality jointly. Toda and Yamamoto (1995) propose an exciting and straightforward procedure requiring the estimation of an augmented VAR which guarantees the asymptotic distribution of the Wald statistic, since the testing procedure is robust to the integration and co-integration properties of the process. This study employs the Toda and Yamamoto (1995) causality test based on the augmented VAR $(p+d \max )$ model. The model produces better results if there is no specification bias (Mohammed \& Jauhari, 2016), when appropriate lag lengths and sample sizes are used (Zapata \& Rambald, 1997).

This technique has many advantages over other techniques. The approach is applicable regardless of the cointegration and integration features of the model. Second, it better controls the types I error probability (Hundie, 2014). Besides, when compared to VECM and VAR, it is the most stable method. Applying the Toda-Yamamoto causality approach, the following equations are estimated to examine the direction of causality between population growth and economic growth in Ethiopia.

$$
\Delta(\ln G D P)_{t}=\delta_{10}+\delta_{11 t}+\sum_{i=1}^{p} \beta_{11 i}\left(\ln G D P_{t-1}\right)+\sum_{i=1}^{p} \beta_{12 i}\left(\ln P O P_{t-1}\right)+\mu_{1 t} \ldots \ldots \ldots
$$

Where, lnGDP and lnPOP are previously defined, $\mathrm{p}$ is the maximum lag order (chosen by AIC and SIC). In the Toda Yamamoto test, the lag length is equal to the optimal lag length (i.e., p) plus the maximum order of integration (i.e., $d \max$ ). This means that the lag order is intentionally over-fitted with an additional lag (Furuoka, 2016), and the total lag length included in the model is set to be $p+d \max$.

$$
\Delta(\ln P O P)_{t}=\delta_{20}+\delta_{22 t}+\sum_{i=1}^{p} \beta_{21 i}\left(\ln P O P_{t-1}\right)+\sum_{i=1}^{p} \beta_{22 i}\left(\ln G D P_{t-1}\right)+\mu_{2 t}
$$

To test the null hypothesis that the population does not Granger causes economic (GDP) growth, the following restriction is specified $H_{01}: \beta_{111}=\beta_{112} \ldots=\beta_{11 L}=0$, where $\beta_{11 i}$ is the coefficient of the restricted lag value of the population in the model. Similarly, to test the second null hypothesis of economic growth does not Granger causes population growth, the restriction is set as $H_{02}: \beta_{211}=\beta_{212 \ldots} \ldots \beta_{21 L}=0$, where $\beta_{21 i}$ is the coefficient of the lag value of economic growth. However, two steps are involved to implementing the procedure. The first step is to select the maximum order of integration $(d \max )$ for the variables in the system and then, the determination of the lag length (p) (Santos \& Chris, 2013).

\section{Results and Discussion}

Figure 1 below shows the growth rate of the population and gross domestic product over the study year. The growth rate of GDP, as indicated by the figure, has been fluctuating over the study period. In some particular periods (such as in 1985, 1991-92 and 1998), the GDP has showed a negative growth rate- this indicates how the economy is volatile. Since the Ethiopian economy is agricultural and traditional, that relies on rainfall, its performance alters. Whereas, the growth rate of population has remained positive throughout the study period. Current estimates show the total population of Ethiopia is 113.17 million people with an annual growth rate of about 3.02 percent per yearincreasing of about 3.4 million people per year. Even though the growth rate of GDP is significantly higher than population growth rate (that is reasonably enough to bring per-capita income growth positive), with the prevailing more significant amount of unemployment rate, poverty, and income inequality, the country's impending overall economic development becomes unreliable.

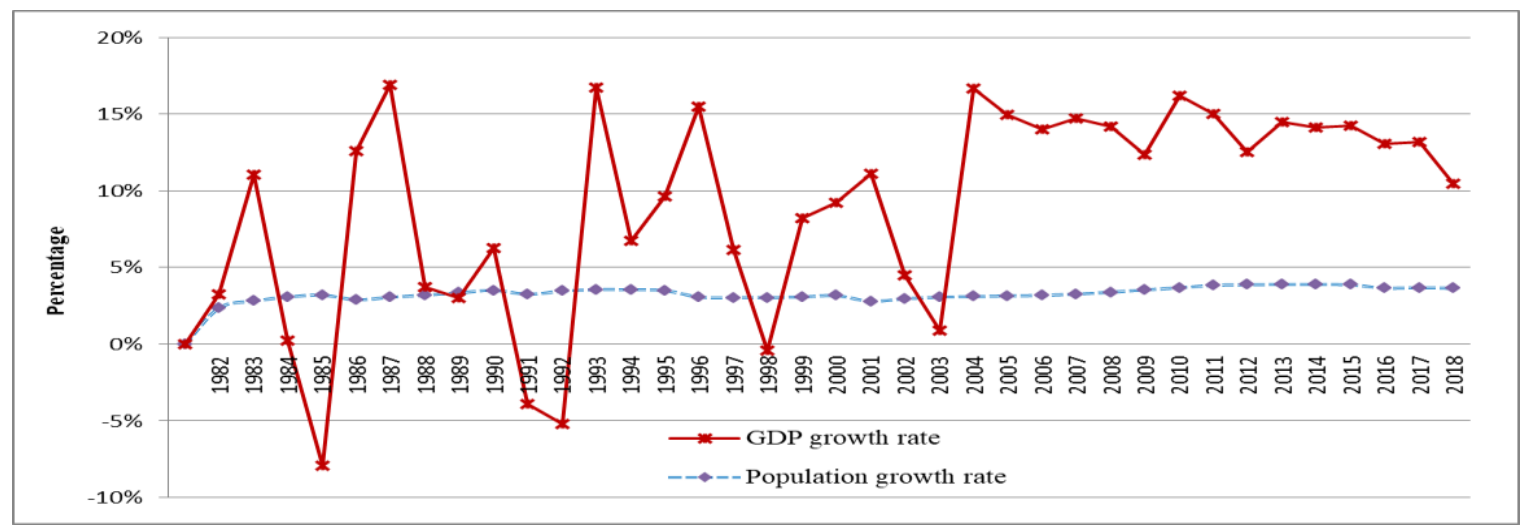

Source: Authors construction from WB data

Figure 1. The growth rate of GDP and population

\section{Unit root tests}

To employ the Granger causality test, performing the unit root and lag length selection criteria tests are necessary. Tests of unit root/Stationarity for the variables of this study are carried out using the Augmented DickeyFuller (ADF) and the Phillips-Perron (PP) stationary tests. The results are presented in Table 1 below. Both tests 
demonstrate that all series are stationary at first difference, I(1). Hence, the form of the data series allowed us to estimate the ARDL model and the Toda-Yamamoto causality examination.

Table 1. Unit root test results

\begin{tabular}{|c|c|c|c|c|c|c|c|c|}
\hline \multicolumn{9}{|c|}{ Augmented dickey fuller(ADF) } \\
\hline \multirow{3}{*}{$\begin{array}{l}\text { Variabl } \\
\text { es }\end{array}$} & \multicolumn{4}{|c|}{ Level I $(0)$} & \multicolumn{4}{|l|}{ Differenced I(1) } \\
\hline & \multirow{2}{*}{$\begin{array}{l}\text { Statistics } \\
\text { test }\end{array}$} & \multicolumn{2}{|c|}{ Critical values } & \multirow[t]{2}{*}{ P-value } & \multirow[t]{2}{*}{ Statistics test } & \multicolumn{2}{|c|}{ Critical values } & \multirow[t]{2}{*}{ P-value } \\
\hline & & $1 \%$ & $5 \%$ & & & $1 \%$ & $5 \%$ & \\
\hline $\operatorname{lnGDP}$ & -0.895067 & -4.226815 & -3.536601 & 0.9459 & -5.326694 & -4.234972 & -3.540328 & $0.0006 *$ \\
\hline $\operatorname{lnPOP}$ & 0.889818 & -4.323979 & -3.580623 & 0.9997 & -6.833106 & -4.323979 & -3.580623 & $0.0000^{*}$ \\
\hline \multicolumn{9}{|c|}{ Phillips-Perron (PP) } \\
\hline & \multicolumn{4}{|l|}{ Level I $(0)$} & \multicolumn{4}{|c|}{ Differenced I(1) } \\
\hline $\operatorname{lnGDP}$ & -0.928514 & -4.226815 & -3.536601 & 0.9417 & -5.326694 & -4.234972 & -3.540328 & $0.0006 *$ \\
\hline $\ln \mathrm{POP}$ & -0.148702 & -4.226815 & -3.536601 & 0.9919 & -3.225715 & -4.234972 & -3.540328 & $0.0956^{* * * *}$ \\
\hline
\end{tabular}

Source: EViews (9) result (2019)

Since the ARDL model is lag sensitive, and the order of the VAR model plays a vital role in empirical analysis, optimal lag length selection should be given distinctive attention. To this end, the optimal lag is determined by Akaike Information Criteria (AIC) and Schwartz Information Criterion (SIC).

\section{Co-integration}

Table 2 below shows the findings from the bounds test for both population and economic growth models. In the first part, economic growth $(\Delta \ln \mathrm{GDPt})$ is modeled as the dependent variable for four different lag lengths. Accordingly, the computed F-statistics fell outside the upper bound of critical values in the estimation models with all four lag orders-implying the existence of a long-run relationship between economic growth and population in Ethiopia. Likewise, following the second part of Table 2, population growth $(\Delta \ln \mathrm{POPt})$ modeled as a dependent variable. As can be seen from the table, the computed F-statistics fell outside the upper bound of critical values in the model with all lag order, except the third one. Therefore, the null hypothesis of no co-integration is rejected for both models, and these results confirmed the existence of a long-run stable relationship between economic growth and population growth in Ethiopia.

Table 2. Bound Co-integration test

\begin{tabular}{|c|c|c|c|c|c|c|}
\hline \multicolumn{7}{|c|}{ Dependent variable: $\Delta \ln \mathrm{GDP}$} \\
\hline \multirow{2}{*}{\multicolumn{3}{|c|}{$\begin{array}{l}\text { Lag length } \\
\text { F-statistic }\end{array}$}} & 1 & 2 & 3 & 4 \\
\hline & & & 15.50161 & 15.50161 & 9.601701 & 7.424288 \\
\hline Significance level & $\mathrm{I}(0)$ & $\mathrm{I}(1)$ & \multirow[t]{3}{*}{ Co-Integration } & \multirow{3}{*}{ Co-Integration } & \multirow{3}{*}{ Co-Integration } & \multirow{3}{*}{ Co-Integration } \\
\hline $5 \%$ & 3.62 & 4.16 & & & & \\
\hline $1 \%$ & 4.94 & 5.58 & & & & \\
\hline \multicolumn{7}{|c|}{ Dependent variable: $\Delta \ln \mathrm{POP}$} \\
\hline \multicolumn{3}{|l|}{ Lag length } & 1 & 2 & 3 & 4 \\
\hline \multicolumn{3}{|l|}{ F-statistic } & 2886.086 & 11.70988 & 1.487904 & 37.65061 \\
\hline Significance level & $\mathrm{I}(0)$ & $\mathrm{I}(1)$ & \multirow{3}{*}{ Co-Integration } & \multirow{3}{*}{ Co-Integration } & \multirow{3}{*}{$\begin{array}{l}\text { No co- } \\
\text { integration }\end{array}$} & \multirow{3}{*}{ Co-Integration } \\
\hline $5 \%$ & 3.62 & 4.16 & & & & \\
\hline $1 \%$ & 4.94 & 5.58 & & & & \\
\hline
\end{tabular}

Source: EViews (9) result (2019)

\section{ARDL Long-run and short-run Coefficients}

Table 3 below indicates the long-run and short-run dynamics. These results are computed by incorporating 2 Optimal lags selected based on AIC and SIC.

Table 3. ARDL Long-run and short run-coefficients

\begin{tabular}{|c|c|c|c|c|c|}
\hline \multicolumn{6}{|c|}{ Dependent variable: $\Delta \operatorname{lnGDP}$} \\
\hline \multicolumn{2}{|l|}{ Lag length $(2)$} & Coefficients & St. Error & t-Statistic & Prob. \\
\hline & Constant & 79.573631 & 31.934358 & 2.491787 & 0.0179 \\
\hline \multirow{2}{*}{$\begin{array}{l}\text { Short-run } \\
\text { Coefficients }\end{array}$} & $\Delta \operatorname{lnPOPt}$ & -4.151450 & 1.684894 & -2.463923 & 0.0191 \\
\hline & ECT & -0.323777 & 0.122458 & -2.643972 & 0.0124 \\
\hline \multirow[t]{3}{*}{ Long-run Coefficients } & $\ln \mathrm{POPt}$ & -12.821956 & 1.831627 & -7.000309 & 0.0000 \\
\hline & @Trend & 0.449661 & 0.055362 & 8.122153 & 0.0000 \\
\hline & \multicolumn{5}{|c|}{ Cointeq = LNGDP - (-12.8220*LNPOP + 0.4497*@TREND) } \\
\hline \multicolumn{6}{|c|}{ Dependent variable: $\Delta \operatorname{lnPOP}(\mathrm{c}$ no trend lag $(2)$} \\
\hline \multicolumn{2}{|l|}{ Lag length $(2)$} & Coefficients & St. Error & t-Statistic & Prob. \\
\hline \multirow{4}{*}{$\begin{array}{l}\text { Short-run } \\
\text { Coefficients }\end{array}$} & Constant & 1.047527 & 0.320543 & 3.267981 & 0.0027 \\
\hline & $\Delta \operatorname{lnPopt-1}$ & 0.828543 & 0.047116 & 17.585179 & 0.0000 \\
\hline & $\Delta \operatorname{lnGDPt}$ & -0.002503 & 0.001249 & -2.003449 & 0.0539 \\
\hline & ECT & -0.056664 & 0.016931 & -3.346709 & 0.0022 \\
\hline Long-run Coefficients & @ Trend & 0.031769 & 0.000884 & 35.951435 & 0.0000 \\
\hline
\end{tabular}




\begin{tabular}{|l|l|l|l|l|}
\hline & $\operatorname{lnGDPt}$ & -0.044168 & 0.011013 & -4.010401 \\
\hline & Cointeq = LNPOP - (-0.0442*LNGDP + 0.0318*@ $@$ TREND) & 0.0004 \\
\hline
\end{tabular}

The table shows the result of the two models. In the first model in which $\Delta \ln \mathrm{GDPt}$ is considered as a dependent variable, population growth affects GDP growth negatively and significantly, both in the short-run and in the longrun. In the second model, $\Delta \ln \mathrm{POPt}$ is considered as a dependent variable. In the short-run and long-run, growth in GDP affects population growth positively and significantly. Moreover, in the short-run, population growth is found to be affected positively and significantly by its own lag.

As can be seen from the table 3 in the above, the coefficient of ECT in the estimation models with economic growth $(\Delta \ln \mathrm{GDPt})$ as a dependent variable is negative and statistically significant at 1 percent level-as prior expected. The significance of the Error correction terms further confirmed the existence of a long-run relationship between population and economic growth in Ethiopia. Accordingly, the speed of adjustment to the equilibrium of growth is $32 \%$ per annum. The error correction term (ECT) of the second model is negative and statistically significantconfirming the presence of a long-run relationship between population and economic growth in Ethiopia. The coefficient of ETC of the second model is -0.056-implying about 5.6 percent of disequilibria in population growth is corrected in each year.

\section{Toda-Yamamoto Granger-Causality Tests}

Table 4 shows the main results of the Toda-Yamamoto causality tests. As indicated in the table, based on the Modified Wald Tests, a unidirectional causality running from population growth (Population) to economic growth (GDP) is found. This paper finds that the null hypothesis of population growth in Ethiopia does not Granger causes economic growth cannot be rejected at a 1 percent significance level. Hence in the last 38 years and so population growth has been affecting the economic growth (GDP growth) of Ethiopia.

Table 4. Toda-Yamamoto Granger-Causality Tests

VAR Granger Causality/Block Exogeneity Wald Tests

\begin{tabular}{|l|c|l|l|l|}
\hline \multicolumn{5}{|l|}{ Dependent variable: LNGDP } \\
\hline Excluded & Chi-sq & Df & Prob. & Conclusion \\
\hline LNPOP & 11.03576 & 2 & $0.0040^{*}$ & Population granger causes GDP \\
\hline Dependent variable: LNPOP & \multicolumn{4}{|l|}{} \\
\hline Excluded & Chi-sq & Df & Prob. & \\
\hline LNGDP & 0.692952 & 2 & 0.7072 & GDP does not granger causes Population \\
\hline
\end{tabular}

Source: EViews (9) result (2019)

Conversely, this paper fails to reject the null hypothesis that economic growth does not cause population growth in Ethiopia. Thus, this study proposes that economic growth is not the cause of population growth in Ethiopia.

\section{Summary and Conclusion}

The link between population growth and economic growth has been becoming of most significant interest researchers. However, there is an agreement between researchers and scholars about whether population growtheconomic growth nexus. Hence, using a time series data spanning form the period 1981 to 2018 , the present study aimed to look at the relationship between population and economic growth in Ethiopia. To this end, the study used; augmented dickey-fuller and Phillip-Perron stationary tests, ARDL co-integration tests, and Toda-Yamamoto Granger-Causality Tests. Accordingly, population growth and economic (Proxied by GDP) have a meaningful longrun relationship, as confirmed by the bound test co-integration approach. From the ARDL model estimate, population growth is found to having a negative and significant effect on economic growth (GDP growth), both in the short-run and in the long-run. Likewise, growth in GDP affects population growth positively and significantly in the short-run and long-run. Moreover, in the short-run, population growth is found to be affected positively and significantly by its own lag. The coefficients of the error correction term (ECT) of the model are negative and statistically significant_confirming the presence of long-run association-ship between population and economic growth in Ethiopia.

The Toda-Yamamoto Granger-Causality Tests revealed that, there is a unidirectional causality between population growth and economic growth-running from population growth (Population) to economic growth (GDP). Hence in the last 38 years and so population growth has been affecting the economic growth (GDP growth) of Ethiopia. Thus, this study recommends that economic growth in Ethiopia is not the primary cause of population growth. The current (as of 2019) number of the total population of Ethiopia exceeds 110 million-making the country the second-most populous nation in Africa. With the prevalence of high fertility rate and mortality rate, unemployment, and poverty, the population is not expected to bring economic development in general and economic growth in particular. Hence, it is advised to the concerned body that anti-natal policies that discourage the fertility rate, need to be re-considered to supplement with economic growth policies.

\section{References}

Adediran, O.A. (2012). Effect of Population on Economic Development in Nigeria: A Quantitative Assessment. International Journal of Physical and Social Sciences. Vol. 2, Issue 5, 1-14. 
Ademola, O.Y. (2019). Economic Growth and Demographic Dividend Nexus in Nigeria: A Vector Autoregressive (VAR) Approach. Asian Social Science; Vol. 15, No. 2. URL: https://doi.org/10.5539/ass.v15n2p37.

Admassie, A., Seid, N.A., John, F.M., Shelley, M. \& Scott, M. (2015). "The Demographic Dividend: An Opportunity for Ethiopia's Transformation," Washington, DC: Population Reference Bureau and Ethiopian Economics Association.

Afzal, M., Farooq, M. S., Ahmad, H. K., Begum, I., \& Quddus, M. A. (2010). Relationship between school education and economic growth in Pakistan: ARDL bounds testing approach to co-integration. Pakistan Economic and Social Review, 39-60.

Aidi, H.O., Emecheta, C. \& Ngwudiobu, I.M (2016). Population and Economic Growth in Nigeria: is there an Empirical Evidence of Causality? International Journal Advances in Social Science and Humanities. Vol.4 | Issue 02 pp.59-66. www.ijassh.com

Akinbode, S.L., Okeowo, K.S. \& Azeez, A.T. (2017). The Dynamics of Population and Economic Growth in Nigeria. Journal of Economics and Development Studies. Vol. 5, No. 3, pp. 79-86. DOI: 10.15640/jeds.v5n3a9.

Asafo, S. S (2018). The Macro-economy and Non-Performing Loans in Ghana: A BVAR approach. International Journal of Business and Economic Sciences Applied Research. 11(3): 65-72 ijbesar.teiemt.gr

Assefa, H. (1994). Population dynamics and their underlying implications for Development in Ethiopia. Conference Paper.

Bloom, David E., Canning, David, \& Sevilla, J. (2003). The Demographic Dividend: A New Perspective on the Economic Consequences of Population Change. Santa Monica, CA: RAND Corporation.

Dao, M. Q. (2012). Population and economic growth in developing countries. International Journal of Academic Research in Business and Social Sciences, 2(1), 6-17.

Dauda, R.S. \& Aziakpono, J.M. (2015). Population Dynamics and Economic Outcomes in West Africa. J.Stud.Econ. Econometrics, $39(3)$.

Dennis, A. \& Robert, C. (2008). Population and development. International handbook of development economics. Cheltenham, UK: Edward Elgar, pp. 316-327.

Dullah, M., Rozilee, A., Mori, K. \& Jaratin, L. (2011). Economic Growth and Population Growth: Empirical Testing Using Malaysian Data. Interdisciplinary Journal of Research in Business. Vol. 1, Issue. 5, (pp.17-24).

Eli, H.T., Mohammed, I.D. and Amade, P. (2015). Impact of Population Growth on Economic Growth in Nigeria (1980-2010). IOSR Journal Of Humanities And Social Science (IOSR-JHSS) Volume 20, Issue 4, PP 115-123. DOI: 10.9790/O8372045115123.

Emmanuel, Y. A. (2015).The Population Growth - Economic Growth Nexus: New Evidence from Ghana. University of Ghana, Legon. Http://Ugspace.Ug.Edu.Gh.

Furuoka, F. (2018). Is population beneficial to economic growth? An empirical study of China. Quality \& Quantity, 52(1), 209-225

Furuoka, F. (2010). Population Growth and Economic Development: Empirical Evidence from the Philippines. Philippine Journal of Development. Number 68, First Semester 2010 Vol. XXXVII, No.1

Hundie, S. K. (2014). Savings, investment and economic growth in Ethiopia: Evidence from ARDL approach to co-integration and TYDL Granger-causality tests. Journal of Economics and International Finance, 6(10), 232.

Jorge, G-R., Cecilia, I.A-V., Karen, D.M-S., and Francisco, D.R-R. \& Pedro, A.V-C.(2016) "The relationship between population growth and economic growth in Mexico", Economics Bulletin, Volume 36, Issue 1, pages 97-107.

Linden, E. (2017, June). Remember the population bomb? It's still ticking. New York Times: Sunday Review, 4.

Malthus, T.R. (1798). An Essay on the Principle of Population, J. Johnson, London.

Matchaya, G.C., Chilonda, P., \& Nhelengethwa, S. (2013). International Trade and Income in Malawi: A Co-integration and Causality Approach. International Journal of Economic Sciences and Applied Research 6(2): 125-147. ijbesar.teiemt.gr

Mohammed, U. \& Jauhari, D. (2016). An Application of Asymmetric Toda-Yamamoto Causality on Exchange Rate-inflation Differentials in Emerging Economies. International Journal of Economics and Financial Issues. 6 (2), 420-426. http: www.econjournals.com

Pesaran, M.H., Shin, Y., \& Smith, R. (2001). Bounds testing approaches to the analysis of level relationships. J. Appl. Econom. 16, 289-326

Santos., R. A. \& Chris, C O.(2013). Toda-Yamamoto Causality Test Between Money Market Interest Rate And Expected Inflation: The Fisher Hypothesis Revisited. European Scientific Journal. Vol.9, No.7 pp.125-142.

Solow, R. M. (1956). A Contribution to the Theory of Economic Growth. The Quarterly Journal of Economics 70, no. 1: 65.

Temitope, S.A., Philip, A.O. \& Sunday, I.O. (2013). Population Dynamics and Economic Growth in Sub-Saharan Africa. Journal of Economics and Sustainable Development Vol.4, No.13, pp 148-157. www.iiste.org

Terefe, D. (2018). Economy and Population in Ethiopia: a search for relations. Journal of Economic \& Social Development, Vol. - XIV, No. 2 , pp, 1-17

Thuku, G. K., Gachanja, P. M., \& Obere, A. (2013). The impact of population change on Economic growth in Kenya. International journal of Economics and management sciences, 2(6), 43-60

Toda, H. Y., \& Phillips, P. C. (1994). Vector Autoregression and causality: A theoretical overview and simulation study. Econometric reviews, 13(2), 259-285.

Toda, H.Y., \& Yamamoto, T. (1995): Statistical inference in vector Autoregressions with possibly integrated process. J. Econom. 66, $225-250$

Umit, A. Oznur \& Alkan, H. Isil (2016). The Effects of Foreign Direct Investments and Economic Growth on Employment and Female Employment: A Time Series Analysis With Structural Breaks For Turkey. International Journal of Business and Economic Sciences Applied Research 9(3): 43-49. http://ijbesar.teiemt.gr

Wesley, F. P. (2017). The Role of Population in Economic Growth. SAGE Open, 1-15. DOI: 10.1 177/2158244017736094.

Zapata, H.O., Rambaldi, A.N. (1997). Monte Carlo evidence on co-integration and causation. Oxford Bulletin of Economics and Statistics, 59(2), 285-298.

Worldometers: (https://www.worldometers.info/world-population/)

Central Intelligence agency (2019). CIA, World Fact Book. (https://www.cia.gov/library/publications/the-worldfactbook/geos/xx.html\#field-anchor-people-and-society-population)

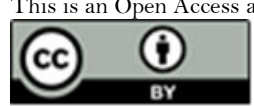

